\title{
Agricultural Productivity of the Baramati Tahsil, Pune District (Maharashtra).
}

\author{
${ }^{1}$ Dr. Sunil Ogale, ${ }^{2}$ Dr. Virendra Nagarale \\ ${ }^{1}$ Assistant Professor Department of Geography, Vidya Pratishthan's A.S.C. College Baramati, Pune District \\ Maharashtra State, India. \\ ${ }^{2}$ Professor and Head Department of Geography S.N.D.T. Women's University Pune Campus, Pune India
}

\begin{abstract}
The present study is an attempt to identify agricultural productivity region of Baramati tahsil in Pune district for its better landuse planning. Baramati tahsil is situated in east part in Pune district covering 1382 square kilometer area and having 479690 populations (2011). This taluka consists of 117 revenue villages with one urban settlement. Administratively, this taluka has divided into six revenue circles. Population density of taluka is 347 persons per square kilometer (2011). The study region extends from 18 $2^{\prime} 44^{\prime \prime} \mathrm{N}$ to $18^{\circ} 23^{\prime} 19^{\prime \prime}$ North latitudes and $74^{\circ} 13^{\prime} 8^{\prime \prime}$ E to $74^{\circ} 42^{\prime} 47^{\prime \prime}$ East longitudes. The region falls under scarcity zone having rainfall between 400 to $500 \mathrm{~mm}$. Monsoon generally commences in June, occurring highest rainfall in June (158 $\mathrm{mm})$ and lowest in December $(12 \mathrm{~mm})$. The highest mean temperature is observed in May $\left(34.6^{\circ}\right.$ centigrade) and lowest in January $\left(18.5^{\circ}\right.$ centigrade). The slope of region is towards northwest and southeast. The study area has basaltic base having step like topography. Baramati tahsil is somewhat rectangular in shape. The study region is mainly agrarian having 84.89 percent net sown area of the total geographical area. Enyedi's method was chosen to compute crop productivity for Baramati tahsil because of its accuracy. Productivity index values were calculated for six sample villages for the year 2010-11 and demarcated the productivity regions as very high, high, medium, low and very low productivity regions. Enyedi's productivity index values were calculated for sample villages are representative to entire tahsil for the year 2010-11 and the productivity regions were demarcated by using the same method for fixing the class intervals as shown in a Map is prepared with the help of productivity Indices.
\end{abstract}

Keywords: Agriculture, Productivity, Productivity index

\section{Introduction}

Agricultural Productivity is a multidimensional concept, which includes technological advancement, effective management of available resources and organizational set-up for the agricultural production. These factors in turn affect the relative production in any region. The term 'Productivity' is regarded as the measurement of production and inputs required for the production of that output is known as agricultural productivity. Agricultural productivity is the interplay of a multitude of many factors, such as environmental, socio-economic and technological factors. Rao and Jasbir Singh (1981) considered "Productivity as the degree at which the economic, cultural, technical and organizational variables are able to exploit the biotic resources of the area for agricultural production". Bhatia (1967) defined agricultural efficiency as, "The aggregate performance of various crops in regard to their output per acre". Singh and Dhillion (2000) suggested that the "yield per unit" should be considered to indicate agricultural productivity. This may be defined as the "ratio of index of local agricultural output to the index of total input used in farm production".

\section{Study Area}

Baramati tahsil lies between $18^{\circ} 2^{\prime} 44^{\prime \prime} \mathrm{N}$ to $18^{\circ} 23^{\prime} 19^{\prime \prime}$ North latitudes and $74^{\circ} 13^{\prime} 8^{\prime \prime}$ E to $74^{\circ} 42^{\prime}$ 47" East longitudes. It is located at an altitude of 538 meters above mean sea level. The tahsil lies in the eastern part of Pune district of Maharashtra. The river Nira flows west to east forming the southern boundary of the Tahsil and the district. The river Karha flows northwest to south-east Baramati tahsil is bounded by Indapur tahsil towards the east, Satara district towards the south, Purandar tahsil towards the west and Daund Tahsil towards the north. The total geographical area (TGA) of Baramati tahsil is $1382 \mathrm{sq} . \mathrm{km}$., which is about 8.80 percent of TGA of the Pune district (See Fig.1). 


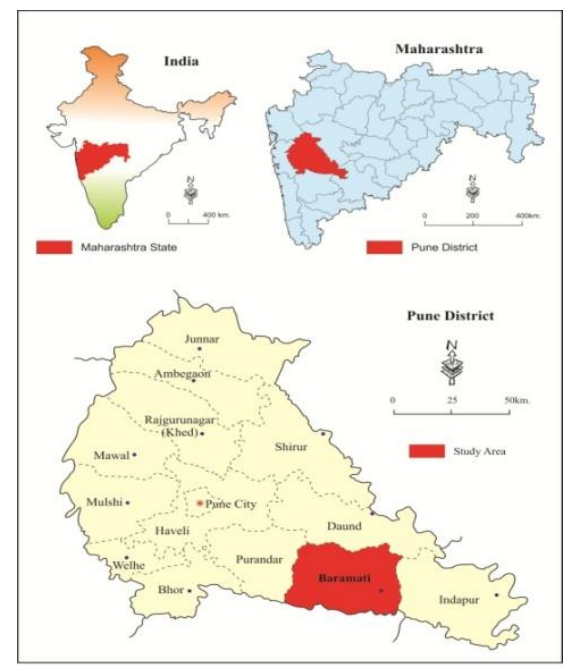

Fig.1 Location Map of the Study Area

\section{Objectives}

i) Examining the physical background.

ii) Identifying agricultural productivity of the Baramati tahsil.

\section{Data Sources and Methodology:-}

The present study aims at computing of crop productivity for Baramati tahsil having diversity in soil, local relief and irrigation. The productivity data, at village level is not available. To overcome this difficulty of yield data of each crop was collected during fieldwork both on yield and acreage for the selected villages. This data has been utilized to obtain crop productivity for these six villages. These six villages are representative to entire tahsil. These villages are 1) Supe, 2) Undavadi Supe, 3) Loni Bhapkar, 4) Vadgaon Nimbalkar, 5) Malegaon Bk. and 6) Baramati Rural. Enyedi's method was chosen to compute crop productivity for Baramati tahsil because of its accuracy. Where, Productivity index $=$

$$
\frac{Y}{Y_{n}} \div \frac{T}{T_{n}} \times 100
$$

$\mathrm{Y} \quad=\quad$ Production of the selected crop in unit area i.e. villages

$\mathrm{Yn} \quad=\quad$ Total Production of the selected crop at regional level (Entire study region)

$\mathrm{T}=\quad$ Area under Selected Crop in unit area (Village level)

$\operatorname{Tn}=\quad$ Total cropped area in entire study region.

Using this formula the productivity index values were calculated for six sample villages for the year 2010-11 and demarcated the productivity regions as very high, high, medium, low and very low productivity regions. Enyedi's productivity index values were calculated for sample villages are representative to entire tahsil for the year 2010-11 and the productivity regions were demarcated by using the same method for fixing the class intervals as shown in a Map is prepared with the help of productivity Indices.

\section{Physiography and Drainage:-}

Baramati tahsil may be divided into two physiographic regions according to altitude. The first one is the hilly track above the 650 meters altitude observed at northwest corner of the tahsil. The other one is gently sloping belt along Nira and its tributary Karha. There are two water divides; one divides the Nira and the Karha basin while the other runs from west to east between Karha and Bhima. The second belt of hilly region runs from northwest to southwest corner of the tahsil. This is the highest point in the region $(650 \mathrm{~m})$ and lies at the junction of the three tahsils of the Pune district viz. Daund, Purandar and Baramati. The hilly zone locally called as Malran (open, non cultivated land) shows that agriculture is poor. The riverine belts along Nira and Karha occupy 40 percent area of the tahsil. This region offers favourable situation for irrigation and hence agro-based development. Topographically, it is almost a plain region with alluvial soils. The generalised direction of slope is from northwest to southeast in the Karha basin and from west to east in the Nira. Baramati tahsil is mainly drained by river Nira and its main tributary Karha. Nira is an important tributary of river Bhima. It is a natural boundary between Pune and Satara District (See Fig. 2). 

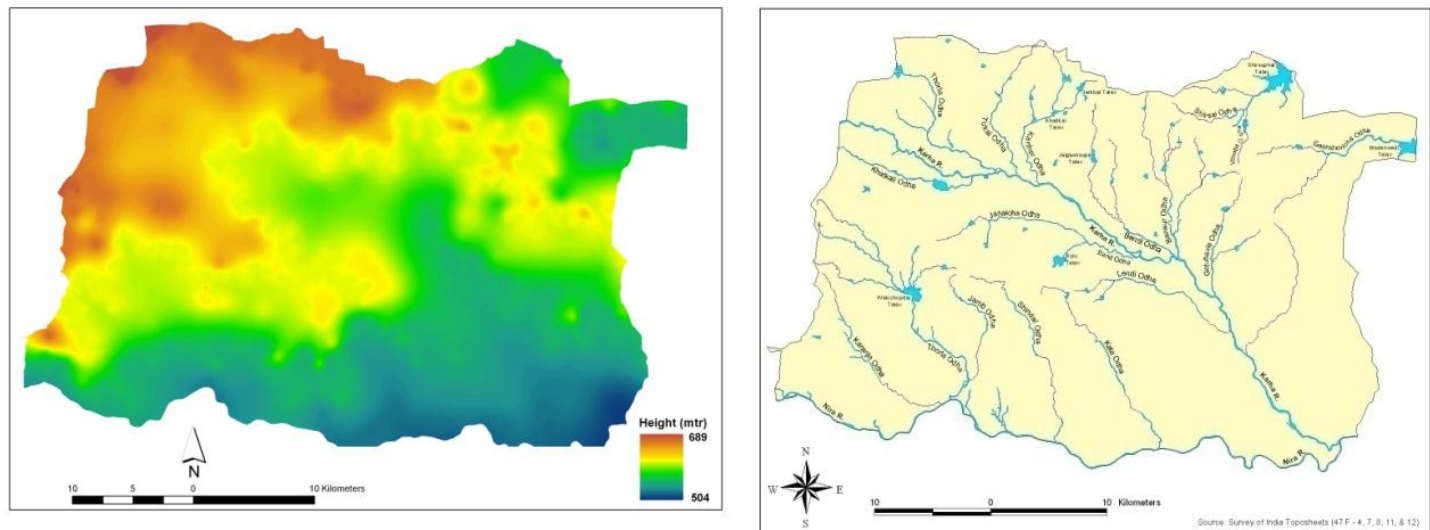

Fig. 2 Physiography and Drainage Map of the Baramati Tahsil

\section{Soil Types:-}

The fertility of soil is one of the factors affecting land capability of agricultural development. There are three types of soil found in the study area, namely, coarse shallow plateau soil, medium deep soil and deep black soil. Coarse shallow soil is observed in the hilly region. The medium black soil appeared in the surrounding area of Nira river and its tributary Karha. This soil is suitable for cultivation of sugarcane, wheat, oilseeds and pulses. The deep black soil lies along the bank of Nira river occupying 20 percent of the study region. This soil is rich in moisture and has high retentive capacity (See Fig. 3 Soil Type of the Baramati Tahsil)

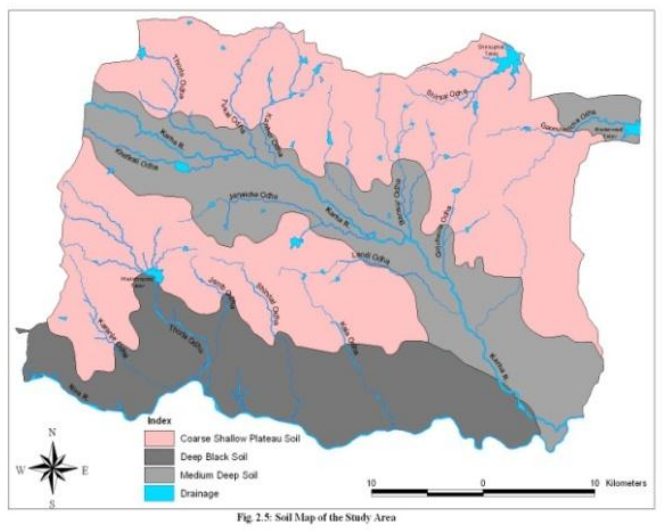

III. Productivity of Jowar

The spatial distribution of productivity of jowar is shown in Table-1 and Fig. 4. It is observed that local topography, soil type and rainfall distribution influence the productivity of jowar. Least productivity is recorded in the South part in the village Malegaon Bk. (59.70) where maximum area is sugarcane cultivation belt and fodder crops and jowar mix crop cultivation this area. Supe village soil is coarse shallow to medium black. Jowar is rabbi crop which requires less amount of water. It is a drought resistant crop. This village situated in the northwest and east shows high productivity i.e. 109.15 and 107.68 respectively. Highest productivity of Jowar is observed in Vadgaon Nimbalkar (149.27) in the south-west part of the study region. The productivity of Jowar is increasing south-west part due to plane topography, medium to deep black soil and irrigation. The productivity pattern of Jowar has increasing trend toward east and west from central pocket of low productivity. Variation of soil type, local relief and rainfall changes in productivity in the west and east part (See Fig. 4).

Table-1 Index Productivity of Jowar in Baramati Tahsil

\begin{tabular}{|l|c|c|c|c|}
\hline Name of the Village & Area Hectare & Total Production Quintal & $\begin{array}{l}\text { Production } \\
\text { Quintal/Hect. }\end{array}$ & $\begin{array}{l}\text { Index of } \\
\text { Productivity }\end{array}$ \\
\hline Supe & 140 & 5600 & 40 & 119.41 \\
\hline Undavadi Supe & 160 & 4800 & 30 & 89.56 \\
\hline Loni Bhapkar & 600 & 15000 & 25 & 74.63 \\
\hline Vadgaon Nimbalkar & 230 & 11500 & 50 & 149.27 \\
\hline Malegaon Bk. & 50 & 1000 & 20 & 59.70 \\
\hline Baramati Rural & 250 & 10000 & 40 & 119.41 \\
\hline Total & 1430 & 47900 & Average 34.16 & - \\
\hline
\end{tabular}

Source: Computed by Researcher. 
Agricultural Productivity of the Baramati Tahsil, Pune District (Maharashtra).

\section{Productivity of Wheat}

Wheat as a rabbi crop is cultivated over medium to deep black soil with subsoil moisture and hence hardly requires irrigation facility. The spatial distribution pattern of wheat productivity is displayed in Fig. 5. Highest productivity of wheat is observed in Baramati Rural (120.48) in the south-east followed by Vadgaon Nimbalkar (108.18) in south-west (Table-2). The lowest productivity is recorded in Loni Bhapkar (49.17) followed by Undavadi Supe (73.86) situated in central and north respectively. The productivity of wheat is increasing towards south-west and south-eastern part due to plane topography, medium to deep black soil and irrigation. Central and northern part have low productivity of wheat due to high relief, coarse shallow soil with low moisture retentive capacity and lack of irrigation facility. Moderate productivity (98.35) is observed in Malegaon Bk. south part due to medium to deep black soil having high moisture retentivity. Vadgaon Nimbalkar, Malegaon Bk. and Baramati Rural have found the three administrative region villages high productivity index (Fig. 5). There is potentiality to large hectarage under wheat by sowing improved varieties of seeds. Irrigation is also a source of high productivity patch well existed in these villages can be utilized for irrigating crops.

Table-2 Index of Productivity of wheat in Baramati Tahsil

\begin{tabular}{|l|c|c|c|c|}
\hline $\begin{array}{l}\text { Name of the } \\
\text { Village }\end{array}$ & Area Hectare & $\begin{array}{l}\text { Total Production } \\
\text { Quintal }\end{array}$ & $\begin{array}{l}\text { Production } \\
\text { Quintal/Hect. }\end{array}$ & $\begin{array}{l}\text { Index of } \\
\text { Productivity }\end{array}$ \\
\hline Supe & 30 & 1350 & 45 & 88.51 \\
\hline Undvadi Supe & 60 & 2250 & 37.5 & 73.76 \\
\hline Loni Bhapkar & 175 & 4375 & 25 & 49.17 \\
\hline Vadgaon Nimbalkar & 290 & 15950 & 55 & 108.18 \\
\hline Malegaon Bk. & 470 & 23500 & 50 & 98.35 \\
\hline Baramati Rural & 450 & 27563 & 61.25 & 120.48 \\
\hline Total & 1475 & 74988 & Average 45.62 & - \\
\hline
\end{tabular}

Source: Computed by Researcher.

\section{Productivity of Bajra}

Bajra, a drought resistant crop of kharif season, is grown on inferior quality soil having less commercial value. The spatial distribution of bajra is depicted in Fig.3. The lowest productivity is three administrative region observed in at Undavadi Supe lies in northern part, Malegaon Bk. and Vadgaon Nimbalkar (83.82) in the south part of the Baramati tahsil. The highest productivity of bajra is recorded at Baramati Rural (127.91) in the south-east part, followed by Supe (125.73) situated in north-west respectively (Table-3 and Fig. 6). The general productivity pattern of bajra shows increasing trend towards north-west and eastern part of the tahsil. The productivity trend of bajra, does not signify any correlation with soil, water and physiography since poorer soils are available at each and every village levels which are generally brought under bajra cultivation. Productivity index of bajra for six selected villages is shown in Table-3.

Table-3 Index of Productivity of Bajra in Baramati Tahsil

\begin{tabular}{|l|c|c|c|c|}
\hline $\begin{array}{l}\text { Name of the } \\
\text { Village }\end{array}$ & Area Hectare & $\begin{array}{l}\text { Total Production } \\
\text { Quintal }\end{array}$ & $\begin{array}{l}\text { Production } \\
\text { Quintal/Hect. }\end{array}$ & $\begin{array}{l}\text { Index of } \\
\text { Productivity }\end{array}$ \\
\hline Supe & 130 & 4875 & 37.5 & 125.73 \\
\hline Undvadi Supe & 140 & 3500 & 25 & 83.82 \\
\hline Loni Bhapkar & 700 & 21000 & 30 & 100.58 \\
\hline Vadagaon Nimbalkar & 220 & 5500 & 25 & 83.82 \\
\hline Malegaon Bk. & 10 & 250 & 25 & 83.82 \\
\hline Baramati Rural & 80 & 3052 & 38.15 & 127.91 \\
\hline Total & 1280 & 38177 & Average 30.11 & - \\
\hline
\end{tabular}

Source: Computed by Researcher.

\section{Productivity of Sugarcane}

Sugarcane is a long duration crop grown in medium black and deep black soil with assured supply of irrigation. The spatial distribution of sugarcane productivity is shown in Fig. 4. The highest productivity of sugarcane is in Baramati Rural (118.38)situated in the south-east part along the bank of river Nira and Karha, followed by Vadgaon Nimbalkar (112.15) situated in south part along the left Nira canal of the study region (Table-4). Lowest productivity of sugarcane is observed in north-west and northern part in Supe (56.07), Loni Bhapkar (49.84) and Undavadi Supe i.e. 62.30. Northern and north-west parts have extensive coverage of high relief, rugged and stony surface of these villages found inferior soil and less productivity of expansion of net sown area. The rugged topography, coarse shallow soil and unavailability of irrigation in the northern part make less productivity of sugarcane. Towards southern part of the tahsil productivity increases due to change in soil type i.e. medium black to deep black, introduction of canal, well and river irrigation where region has plain topography gently sloping towards Nira and Karha basin (See Fig. 7). 
Agricultural Productivity of the Baramati Tahsil, Pune District (Maharashtra).

\begin{tabular}{|c|c|c|c|c|}
\hline $\begin{array}{l}\text { Name of the } \\
\text { Village }\end{array}$ & Area Hectare & $\begin{array}{l}\text { Total Production } \\
\text { Quintal }\end{array}$ & $\begin{array}{l}\text { Production } \\
\text { Quintal/Hect. }\end{array}$ & $\begin{array}{l}\text { Index of } \\
\text { Productivity }\end{array}$ \\
\hline Supe & 30 & 3375 & 112.5 & 56.07 \\
\hline Undvadi Supe & 70 & 8750 & 125 & 62.30 \\
\hline Loni Bhapkar & 75 & 7500 & 100 & 49.84 \\
\hline Vadgaon Nimbalkar & 310 & 69750 & 225 & 112.15 \\
\hline Malegaon Bk. & 800 & 150000 & 187.5 & 93.45 \\
\hline Baramati Rural & 500 & 118750 & 237.5 & 118.38 \\
\hline Total & 1785 & 358125 & Average 164.58 & - \\
\hline
\end{tabular}

Source: Computed by Researcher.

The productivity of sugarcane is increasing in south to north-east direction. This region, physiographically lies in the Nira left canal and the bank of river Nira and Karha. Moreover, it is observed that south and north-eastern part of the villages yield very high productivity of sugarcane than south part due to high fertility of soils. The region included in Vadagaon Nimbalkar, Malegaon Bk. and Baramati Rural of the study area (Fig. 7).

\section{Conclusion}

Crop productivity is a combined effect of physio-socio-economic factors. The physiography has direct influence on the soil types and its spatial distribution. Among all crops, the productivity shows increasing trend toward south to north in the study area. It is an indication of development in agriculture sector. In northern part due to adverse relief condition, coarse shallow soil and non-availability of irrigation leads to low productivity. So there is needed to get financial support and integrated efforts for development of agriculture to reduce regional disparities in Baramati tahsil.

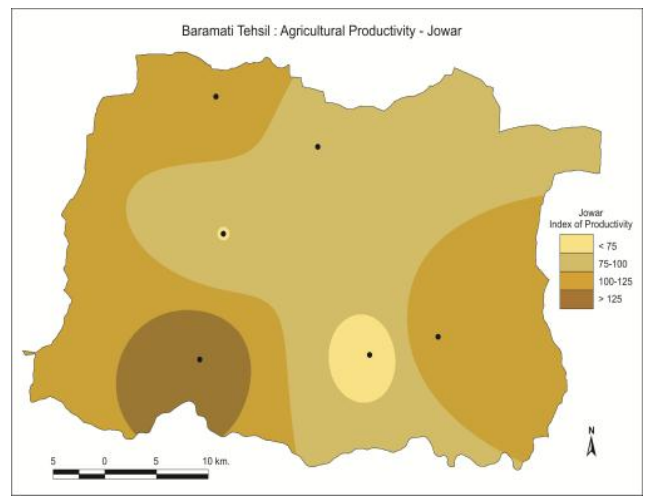

Fig. 4

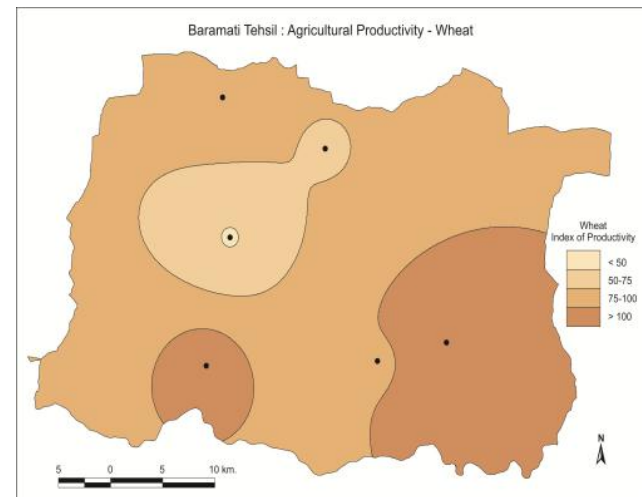

Fig. 6

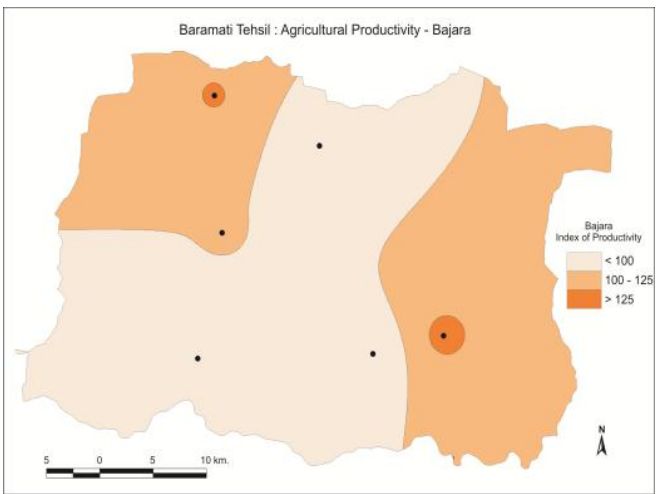

Fig. 5

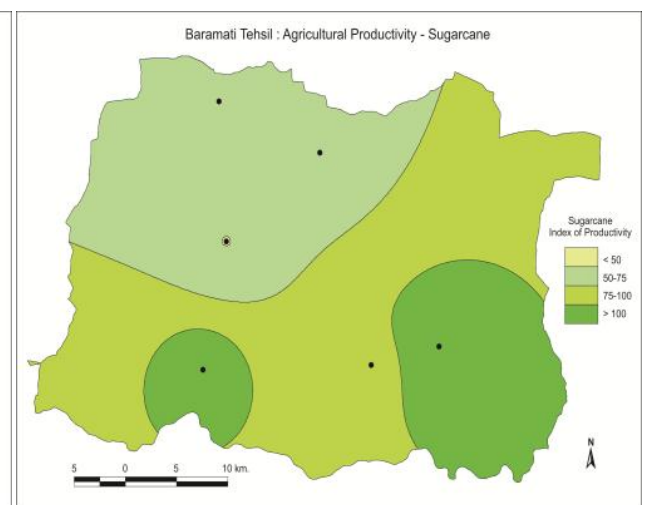

Fig. 7

\section{References}

[1]. Bhatia, S.S. (1967): "A New Approach to Measure Agricultural Effieiency in Uttar Pradesh, Economic Geography", Vol. 43, Pp. 224-260.

[2]. Bhatia, S.S. (1967) : "Spatial Variation, Changes and Trends in Agricultural Efficiency in Uttar Pradesh, 1953-1963". Indian Journal of Agricultural Economics, Vol. 22,

[3]. Jasbir Singh (1981) : "A New Technique for Measurement of Agricultural Productivity-A Perspective in Agricultural Geography", Vol.4, Mohammed Noor, (Ed.) Pp. 169-182. 
[4]. Jasbir Singh (1976): 'Regional Imbalance in the Levels of Food crops Productions: An Agricultural Geography of Haryana'.

[5]. Singh, J. and Dhillon, S.S. (1984) : “An Agricultural Geography”. Tata- McGraw-Hill, Publishing Company Limited, New Delhi.

[6]. Todkari G.U. (2012) : "Impacts of Irrigation on Agricultural Productivity in Solapur District of Maharashtra

[7]. State".International Journal of Agriculture Sciences, Volume 4, Issue 1, 2012, pp-165-167. 